\title{
GAMBARAN PENGGUNAAN INTERNET DALAM MENCARI INFORMASI KESEHATAN PADA SISWA SEKOLAH MENENGAH PERTAMA (SMP) $X$
}

\author{
DESCRIPTION OF INTERNET USE IN SEARCHING HEALTH \\ INFORMATION ON JUNIOR HIGH SCHOOL STUDENT X
}

\author{
Luthfiana Nur \\ Departemen Promosi Kesehatan dan Ilmu Perilaku \\ Fakultas Kesehatan Masyarakat, Universitas Airlangga Surabaya \\ Email: luthfiana.nur-2014@fkm.unair.ac.id
}

\begin{abstract}
Adolescents become a transitional period, in which children will give birth to many more within themselves, physically and mentally. The Internet is one network that can help us to get all the information. The existence of the internet can be beneficial for teenagers, but also can contribute a great negative to their lives. The Internet provides benefits for teenagers, including to improve their health. However many hoax news spread on the internet, this is what applies to porn information that is not true. So this study was conducted to find information about the internet health information in SMP X. Sampling in this penelitain is the total sampling. The results of this study is the teacher of the percentage of $27.0 \%$ or 17 respondents as the first informant about the internet. Not all respondents have media to surf, this is done with the results of research with the number 28 (44.4\%) respondents who do not have media to surf. mobile phone is the main media that respondents choose to surf with the number 28 (36.5\%). More than they choose to seek information as the main goal with a number of 23 respondents or equal to $36.5 \%$. The information used by the respondents is educational information with the number 27 (42.9\%). There are 43 respondents who claimed to have used the internet to seek health information. Many respondents stated that health information on the internet can not help them, those with 33 (52.4\%). A frequent response after getting health information from inetrnet is additional information for a friend with number 19 (30,2\%). In this study can be concluded that adolescents with accessibility to find information, especially about health must be supervised by people who are more capable and more able to filter information.
\end{abstract}

Keywords: youth, internet, health

Abstrak: Remaja merupakan masa peralihan, dimana anak akan mengalami banyak sekali
perubahan dalam dirinya baik secara fisik, psikologi dan perubahan lainnya. Internet salah
satu satu hasil dari sebuah perkembangan teknologi yang dapat membantu kita untuk
mendapatkan segala infomasi. Adanya internet dapat bermanfaat bagi remaja, namun juga
dapat menimbulkan dampak negatif yang besar bagi kehidupan mereka. Internet
memberikan limpahan manfaat bagi remaja, termasuk untuk meningkatkan derajat
kesehatan mereka. Namun banyak berita hoax tersebar di internet, hal inilah yang
mengancam remaja terhadap informasi yang tidak benar. Maka penelitian ini dilakukan
untuk mengetahui gambaran pemakaian internet terhadap pencarian informasi kesehatan di
SMP X. Pengambilan sampel dalam penelitian ini adalah total sampling sebanyak 63 siswa.
Hasil penelitian ini adalah Guru memperoleh persentase $27,0 \%$ atau 17 responden sebagai
informan pertama mengenai internet. Tidak semua responden memiliki media untuk
berinternet, hal ini ditunjukkan oleh hasil penelitian dengan angka 28 (44,4\%) responden
yang tidak memiliki media untuk berinternet. Smartphone merupakan media utama yang
responden pilih untuk berinternet dengan angka 28 (36,5\%). Kebanyakan dari mereka
memilih mencari informasi sebagai tujuan utama berinternet dengan angka 23 responden
atau sama dengan 36,5\%. materi informasi yang sering dicari oleh responden adalah 
informasi pendidikan dengan angka 27 (42,9\%). Terdapat 43 (68,3\%) responden yang mengaku pernah memanfaatkan internet untuk mencari informasi kesehatan. Banyak responden menganggap bahwa informasi kesehatan di internet tidak dapat membantu mereka, pilihan jawaban ini memiliki angka 33 (52,4\%). Respon yang sering responden melakukan setelah mendapatkan informasi kesehatan dari internet adalah membagikan informasi tersebut kepada teman dengan angka 19 (30,2\%). Pada penelitian ini dapat disimpulkan bahwa remaja dengan kemudahan aksesnya mencari informasi, khususnya perihal kesehatan tentu harus diawasi oleh orang yang lebih mengerti dan lebih bisa menyaring informasi.

Kata Kunci: remaja, internet, kesehatan

\section{PENDAHULUAN}

Remaja merupakan masa peralihan anak-anak menuju dewasa. Hal ini sejalan dengan pernyataan Papalia, dkk (2001) bahwa masa remaja adalah masa transisi perkembangan antara masa kanak-kanak dan masa dewasa yang pada umumnya dimulai pada usia 12 atau 13 tahun dan berakhir pada usia belasan atau dua puluhan tahun. Pada masa transisi tersebut remaja mengalami banyak perubahan dalam hidupnya. Beberapa diantaranya adalah perubahan fisik, perubahan psikologis dan beberapa perubahan lainnya. Perubahan-perubahan tersebut menyebabkan banyak gangguan yang terjadi pada diri remaja. Gangguan tersebut disebabkan oleh proses adaptasi diri seorang remaja terhadap berbagai perubahan yang dialaminya. Hal ini sejalan dengan Aryatmi, dkk (1991) yang menyatakan penyesuaian tersebut cukup berat dan pada segi-segi tertentu menimbulkan ketegangan dalam kehidupan remaja pada umumnya. Sering kali remaja tidak dapat memahami dirinya sendiri. Sebab dalam proses perkembangannya remaja akan merasakan gejolak dalam dirinya atau biasa disebut dengan pencarian jati diri. Selain itu karakteristik dari remaja adalah emosi yang tidak stabil. Dalam hal ini remaja biasanya memiliki emosi yang berkobarkobar, mudah marah, terkadang remaja juga merasa tidak bergairah, malasmalasan. Tak jarang remaja juga mengalami perubahan mood yang sangat cepat. Masalah lain yang sering dihadapi oleh ramaja adalah perasaan menentang dalam diri sendiri, perasaan tersebut ada ketika remaja memiliki pendapat dan keinginan yang berbeda dengan kemampuan dan tuntutan yang ada, maka tak jarang mereka akan mengalami kebingungan. Kebingungan tersebut akan memunculkan pertentangan dalam dirinya, baik menentang keadaan, tuntutan maupun keinginannya sendiri. Beberapa karakteristik remaja lainnya adalah suka bereksplorasi, memiliki banyak keinginan dan suka berkhayal. Semua hal tersebut merupakan transisi seseorang menuju dewasa, maka dari itu remaja membutuhkan perhatian dan pengawasan khusus agar proses perkembangan remaja menjadi optimal dan siap menjalani kehidupan dewasa dengan baik.

Sebelumnya telah diulas bahwa masa remaja dimulai pada usia 12 atau 13 tahun. Sedangkan rentang usia remaja menurut Mappiare dalam Alidan Ansori (2012) berlangsung antara usia 12 tahun sampai 21 tahun bagi wanita dan 13 tahun sampai 22 tahun bagi pria. Usia awal menginjak masa remaja adalah masa dimana seseorang berada pada bangku Sekolah Menengah Pertama. Remaja awal, pada tahap ini berada pada rentang usia 1215 tahun, umumnya remaja tengah berada di masa sekolah menengah pertama (SMP) (Sa'id. 2015). Sehubungan dengan kondisi tersebut siswa SMP juga memiliki problematika yang sama seperti karakteristik remaja awal lainnya, emosi tidak stabil, mudah marah, mengalami perubahan mood dengan cepat dan karakteristik remaja lainnya. Maka siswa SMP pun membutuhkan pengawasan khusus.

Salah satu karakteristik yang perlu mendapatkan perhatian lebih adalah eksplorasi. Kegemaran remaja, khususnya pada tahap remaja awal adalah eksplorasi. 
Remaja memiliki rasa penasaran yang lebih daripada tahap perkembangan diri manusia lainnya. Biasanya remaja akan melakukan apapun untuk menemukan jawaban dari pertanyaan yang muncul dalam dirinya. Selain itu remaja juga memiliki karakteristik gemar mencoba, maka ia akan mencoba apapun yang baru ia temukan tanpa memikirkan apa risiko yang akan mereka dapatkan. Hal ini sejalan dengan Ediati (2015) yang menyatakan remaja perlu mendapatkan perhatian serius dan penanganan segera. Hal ini karena remaja merupakan masa transisi yang sangat rentan, dalam masa ini remaja membutuhkan pendampingan yang luar biasa. Remaja dikatakan sebagai kelompok rentan karena jika seorang remaja lepas pengawasan ia dapat terjerumus ke dalam berbagai hal negatif. Namun sebaliknya jika seorang remaja dapat mengoptimalkan proses perkembangannya, maka akan tercipta pribadi yang baik dan siap menjalani kehidupan selanjutnya.

Jaman berkembang sangat pesat, diikuti dengan perkembangan teknologi yang luar biasa. Kondisi ini menciptakan sebuah peluang besar bagi remaja untuk mempermudah mencari jati dirinya, mencari jawaban dari setiap pertanyaan yang muncul, mencoba berbagai hal, mencari tahu apapun yang ia ingin tahu. Salah satu media yang tersedia sebagai akses remaja untuk mendapatkan semua hal tersebut adalah internet. Internet merupakan kumpulan komputer yang membentuk jaringan di seluruh dunia sehingga dapat saling terhubung. Hal ini sejalan dengan Sidharta (1996) yang menyatakatan bahwa internet merupakan interkoneksi sebuah jaringan komputer yang dapat memberikan layanan informasi secara lengkap. Selain itu internet juga merupakan akses informasi tak terbatas, dapat digunakan dimanapun, kapanpun dan oleh siapapun. Hal tersebut tentu memudahkan remaja untuk mengakses apapun yang ingin ia ketahui, terlebih remaja dapat menggunakan gadget yang ia miliki sebagai media untuk mengakses internet.

\begin{tabular}{lccr}
\multicolumn{2}{c}{ Penggunaan } & gadget & dapat \\
memberikan dampak & positif & bagi \\
kelangsungan & hidup & remaja, & selain
\end{tabular}

informasi, internet juga dapat digunakan sebagai akses komunikasi, game, serta dapat digunakan sebagai media pengiriman surat elektronik. Kehidupan manusia, terlebih remaja dapat terbantu dengan adanya internet. Namun internet juga dapat memberikan dampak negatif jika digunakan secara berlebihan dan tanpa pengawasan, selain itu dapat menyebabkan kecanduan. Berdasarkan hasil studi pendahuluan di SMP X 9 dari 10 siswa merupakan pengguna internet. Sedangkan 6 dari 9 siswa tersebut mengaku menggunakan internet lebih dari 3-4 jam sehari. Kusuma (2016) mengatakan seseorang jika menggunakan internet lebih dari 25 jam dalam seminggu maka dapat dikatakan seseorang tersebut adalah pecandu internet. Hal tersebut menyimpulkan bahwa 6 dari 9 siswa di SMP X telah mendekati kata candu dalam berinternet.

Faktanya memang banyak konten dalam internet yang berdampak positif bagi kehidupan seseorang. Tak hanya sebagai ajang berbagi dan mencari informasi, tetapi internet juga dapat menjadi pertunjukan bagi mereka yang tidak tahu arah, internet juga dapat menjadi lapak bisnis yang luas, selain itu internet juga dapat menjadi sumber informasi dan berbagi konten-konten kesehatan. Maka secara tidak langsung, internet dapat membantu seseorang untuk meningkatkan derajat kesehatan.

Penelitian ini dilakukan untuk mengetahui gambaran penggunaan internet dalam mencari informasi kesehatan pada seluruh siswa SMP X. Sehingga dari penelitian ini dapat ditarik kesimpulan kegiatan apa saja yang mereka lakukan pada saat berinternet, serta bagaimana siswa SMP $X$ menggunakan internet sebagai sumber informasi kesehatan.

\section{METODE}

Jenis penelitian ini merupakan penelitian deskriptif analitik (Saputri, 2014). Deskriptif analitik merupakan penelitian yang dilakukan untuk mendapatkan gambaran tentang suatu keadaan secara objektif, sedangkan model penelitian adalah survey. Pengambilan sampel pada penelitian ini menggunakan 
total sampling, dimana semua siswa menjadi responden dalam penelitian ini. Cara ini dipilih karena jumlah siswa yang terlalu sedikit, yaitu 63 siswa SMP X.

Pengambilan data dilakukan terhadap seluruh siswa SMP $X$ sebagai responden dengan cara memasuki ruangan masing-masing kelas dengan jumlah sebanyak 3 kelas secara bergantian. Pengambilan data di lapangan membutuhkan waktu 3 hari, dikarenakan peneliti diperbolehkan memasuki kelas secara bergantian di hari yang berbeda.

\section{HASIL DAN PEMBAHASAN}

Tabel 1. Karakteristik Responden

\begin{tabular}{ccc}
\hline $\begin{array}{c}\text { Karaketristik } \\
\text { Responden }\end{array}$ & Frekuensi & \% \\
\hline Laki-Laki & 16 & 25,4 \\
Perempuan & 47 & 74,6 \\
\hline Usia & Frekuensi & $\mathbf{( \% )}$ \\
\hline 11 Tahun & 0 & 0 \\
12 Tahun & 6 & 9,5 \\
13 Tahun & 10 & 15,9 \\
14 Tahun & 22 & 34,9 \\
15 Tahun & 21 & 33,3 \\
16 Tahun & 4 & 6,3 \\
\hline
\end{tabular}

Tabel 2.Pengenalan Internet dan Teman iBerinternet

\begin{tabular}{ccc}
\hline Pilihan & Frekuensi & $\%$ \\
\hline \multicolumn{3}{c}{ Internet Dikenalkan Oleh } \\
\hline Keluarga & 10 & 15,9 \\
Guru & 17 & 27,0 \\
Teman & 16 & 25,4 \\
Pacar & 9 & 14,3 \\
Sendiri & 11 & 17,5 \\
\hline \multicolumn{3}{c}{ Teman Berinternet } \\
\hline Orangtua & 7 & 11,1 \\
Teman & 31 & 49,2 \\
Pacar & 9 & 14,3 \\
Guru & 6 & 9,5 \\
Saudara & 10 & 15,9 \\
\hline
\end{tabular}

Berdasarkan Tabel 2 dapat diketahui bahwa dari 63 responden pertama kali mengenal internet dari keluarga sebanyak 10 siswa (15,9\%), 17 siswa $(27,0 \%)$ dari Guru, teman sebanyak 16 siswa $(25,4 \%)$, pacar sebanyak 9 siswa $(14,3 \%)$, dan 11 siswa $(17,5 \%)$ mengenal internet dengan mencari tahu sendiri. Jawaban yang paling banyak dipilih oleh responden perihal pengenalan internet pertama kali adalah Guru dengan frekuensi 17 atau 27,0\%. Sedangkan frekuensi jawaban yang paling sedikit adalah teman dekat atau pacar dengan angka 9 atau 14,3\%. Maka dapat disimpulkan bahwa Guru memegang peranan penting bagi siswa SMP X sebagai informan utama perihal pengenalan internet. SMP X berada disebuah desa di Kecamatan Burneh, Kabupaten Bangkalan, Madura. Oleh karena letaknya yang berada di sebuah desa jauh dari keramaian kota SMP X mengalami permasalahan terhadap kesenjangan pendidikan seputar fasilitas, dan Sumber Daya Manusia(SDM) yang tentu akan berpengaruh terhadap kualitas siswa. Hal ini dibenarkan oleh Wakil Kepala Sekolah SMP X yang menyatakan bahwa SMP X memang berbeda dengan SMP lain di kota, fasilitas SMP X terkesan apa adanya. Jika di sekolah lain memiliki Laboratorium Komputer lengkap dengan beberapa perangkat komputer beserta Internetnya, perpustakaan dengan barisan bakuny. Laboratorium IPA dengan berbagai alat-alatnya, dan UKS dengan alat medis dasarnya, berbeda dengan SMP X yang tidak memiliki semua hal tersebut. Maka secara kualitas siswa SMP X jauh berbeda jika dibandingkan dengan SMP lainnya. Hal ini dibenarkan oleh Simbolon (2017) yang mengatakan sarana dan prasarana sangat memengaruhi kemampuan siswa dalam belajar, karena fasilitas (sarana dan prasarana) merupakan penunjang pendidikan.

Selain fasilitas, terdapat hal lain yang memengaruhi kualitas pendidikan. Hal tersebut adalah latar belakang ekonomi atau biasa disebut dengan status ekonomi. Siswa-siswa SMP X mayoritas memiliki status ekonomi yang menengah kebawah. Berdasarkan studi pendahuluan, hal ini dibenarkan oleh Kepala Sekolah SMP X yang mengatakan bahwa mayoritas 
orangtua dari siswa-siswi di SMP X adalah petani dengan kehidupan yang sederhana, mayoritas juga berpendidikan rendah. Status ekonomi memiliki pengaruh terhadap tingkat pengetahuan anak. Hal ini juga akan berpengaruh terhadap hasil belajar mereka selama di sekolah. Menurut Ayudiah (2017) dalam penelitiannya, menuliskan terdapat hubungan status ekonomi keluarga terhadap tingkat pengetahuan remaja, status ekonomi tinggi akan meningkatkan pengetahuan remaja. Sedangkan latar belakang pendidikan orang tua memengaruhi status ekonomi keluarga. Hal ini dibenarkan oleh Basrowi dan Juariyah (2010) dalam hasil penelitiannya bahwa masyarakat yang memiliki latar belakang pendidikan rendah juga memiliki status ekonomi yang rendah. Maka dapat disimpulkan orangtua dengan status ekonomi rendah, mayoritas juga berpendidikan rendah. Orangtua tersebut akan mendidik anak dengan apa adanya serta mengandalkan guru sebagai role model pengetahuan dan pendidikan anaknya.

Berdasarkan paparan yang telah dikemukakan, dapat disimpulkan bahwa guru memiliki peranan utama dalam pengetahuan dan pendidikan siswa SMP X. Hal tersebut menyebabkan Guru harus bekerja lebih keras untuk memberikan pengetahuan kepada siswa, sehingga siswa tidak mengalami kesenjangan pendidikan. Seiring berkembangnya jaman, Guru SMP $\mathrm{X}$ memiliki kewajiban untuk mengupgrade ilmu kepada siswa. Salah satu ilmu yang harus diajarkan adalah Komputer, Gadget dan Internet. Guru harus tetap mempekenalkan ilmu tersebut kepada siswa, meskipun SMP X memiliki keterbatasan fasilitas tersebut. Hal ini dikarenakan guru merupakan role model pengetahuan utama yang mereka miliki.

\section{Teman Pada Saat Berinternet}

Berdasarkan Tabel 2 menunjukkan siswa yang menggunakan internet bersama orangtua sebanyak $7(11,1 \%), 31(49,2 \%)$ untuk teman, angka $9(14,3 \%)$ untuk pacar, $6(9,5 \%)$ untuk guru, dan $10(15,9 \%)$ untuk saudara. Hal ini tentu sangat berbeda dengan tabel sebelumnya yang menyatakan bahwa mayoritas siswa SMP X mengaku guru sebagai informan utama perihal internet. Tabel 2 menunjukkan mayoritas siswa SMP X menjadikan teman sebagai partner berinternet. Sedangkan minoritas dari mereka memilih guru sebagai partner berinternet.Hal ini sejalan dengan Sarmin (2017) yang menyatakan bahwa teman yang sebaya akan menimbulkan hubungan saling percaya dan nyaman. Sehingga remaja akan merasa lebih memilih teman (sebaya) sebagai partner dalam setiap kegiatannya. Sarmin (2017) juga menyatakan bahwa remaja lebih percaya teman (sebaya) dari pada orangtua atau orang yang lebih tua karena kepercayaan timbul karena rasa nyaman yang mereka rasakan terhadap teman (sebaya) lebih besar dari pada orang yang lebih tua.

Selain itu yang melatarbelakangi siswa untuk berinternet bersama teman (sebaya) adalah keterbatasan fasilitas yang ia pribadi miliki. Karena tidak semua siswa memiliki media untuk berinternet. Hal ini sejalan dengan Tabel 3.

Tabel 3. Kepemilikan Media dan Media yang Dimiliki Untuk Berinternet

\begin{tabular}{ccc}
\hline $\begin{array}{c}\text { Pilihan } \\
\text { Kepemilikan }\end{array}$ & $\begin{array}{c}\text { Frekuensi } \\
\text { Media Internet }\end{array}$ & $\%$ \\
Ya & 35 & 55,9 \\
Tidak & 28 & 44,4 \\
\hline \multicolumn{3}{c}{ Media Yang Dimiliki Untuk } \\
Berinternet \\
\hline Komputer & 6 & 9,5 \\
Smartphone & 23 & 36,5 \\
Tab & 0 & 0 \\
Laptop & 6 & 9,5 \\
Tidak Ada & 28 & 44,4 \\
\hline
\end{tabular}

Jumlah siswa yang mengaku memiliki media untuk berinternet tidak jauh berbeda jika dibandingkan siswa yang tidak memiliki media untuk berinternet yaitu 35 (55,9\%) untuk mereka yang mengaku memiliki media, dan $28(44,4 \%)$ bagi mereka yang mengaku tidak memiliki media untuk berinternet. Berdasarkan Tabel 3 menunjukkan bahwa tidak semua siswa memiliki media untuk berinternet, maka bagi mereka yang tidak memiliki internet sering kali memilih berselancar dalam internet bersama teman. 


\section{Media yang dimiliki untuk berinternet}

Bedasarkan tabel 3 menunjukkan bahwa mayoritas siswa SMP X memilih smartphone sebagai media yang digunakan untuk berinternet, yaitu $23(36,5 \%), 6$ $(9,5 \%)$ untuk komputer, dan $6(9,5 \%)$ untuk laptop serta $28(44,4 \%)$ lainnya mengaku tidak memiliki media untuk berinternet. Sedangkan tablet memiliki angka $0(0 \%)$. Hal ini disebabkan karena sebagian besar dari mereka tidak mengenal media yang bernama tablet tersebut. Smartphone menempati posisi utama sebagai media pilihan yang dimiliki oleh siswa untuk mengakses internet. Ternyata hal ini juga diungkapkan Husni dan Fatulloh (2016) yang menuliskan dalam penelitiannya didapat kesimpulan bahwa smartphone menjadi media utama yang digunakan untuk mengakses internet. Hal ini karena smartphone merupakan media yang mudah dioperasikan dan mudah didapat.

Remaja lebih suka menggunakan smartphone sebagai media internet daripada media lainnya. Hal tersebut disampaikan oleh Ayuwuragil (2018) dalam cnnindonesia.com yang menyatakan bahwa hanya 4,49\% dari 2500 responden yang mengaku menggunakan komputer atau laptop sebagai media internet serta $44,16 \%$ mengaku menggunakan smartphone sebagai media untuk berinternet. Smartphone banyak dipilih sebagai media utama berinternet bagi remaja karena smartphone memiliki ukuran yang kecil, dan dapat dibawa kemana saja dengan mudah, serta memiliki fungsi yang hampir sama dengan Laptop PC. Ketika siswa SMP X ditanya tujuan berinternet, sebagian besar dari mereka menjawab mencari informasi dengan angka 23 (36,5\%). Hal tersebut menunjukkan bahwa sebagian besar dari remaja menggunakan internet sebagai sumber informasi apapun yang ingin ia ketahui. Sesuai dengan karateristik remaja dengan rasa ingin tahu yang tinggi, serta kebiasaan mereka untuk mencoba berbagai hal baru, hal tersebut dapat remaja dapatkan melalui media internet. Maka dapat disimpulkan bahwa internet dapat membantu remaja untuk melewati masa pertumbuhannya. Pilihan terbanyak kedua yang dipilih oleh siswa SMP X adalah
Tabel. 4 Tujuan Berinternet Dan Informasi Yang Sering Dicari Melalui Internet

\begin{tabular}{|c|c|c|}
\hline Pilihan & Frekuensi & $\%$ \\
\hline \multicolumn{3}{|c|}{ Tujuan Berinternet } \\
\hline $\begin{array}{l}\text { Mencari } \\
\text { Informasi }\end{array}$ & 23 & 36,5 \\
\hline $\begin{array}{l}\text { Sosial } \\
\text { Media }\end{array}$ & 19 & 30,2 \\
\hline Game & 9 & 14,3 \\
\hline $\begin{array}{l}\text { Membaca } \\
\text { Berita }\end{array}$ & 6 & 9,5 \\
\hline $\begin{array}{l}\text { Menonton } \\
\text { Film }\end{array}$ & 6 & 9,5 \\
\hline \multicolumn{3}{|c|}{$\begin{array}{c}\text { Informasi Yang Sering Dicari } \\
\text { Melalui Internet }\end{array}$} \\
\hline $\begin{array}{l}\text { Informasi } \\
\text { Kesehatan }\end{array}$ & 9 & 14,3 \\
\hline $\begin{array}{l}\text { Informasi } \\
\text { Pendidikan }\end{array}$ & 27 & 42,9 \\
\hline $\begin{array}{c}\text { Informasi } \\
\text { Kuliner }\end{array}$ & 9 & 14,3 \\
\hline $\begin{array}{c}\text { Informasi } \\
\text { Berita }\end{array}$ & 7 & 11,1 \\
\hline $\begin{array}{l}\text { Informasi } \\
\text { Lainnya }\end{array}$ & 11 & 17,5 \\
\hline
\end{tabular}

Sosial Media dengan angka 19 (30.2\%). Sosial Media merupakan ladang komunikasi secara online, dimana remaja dapat membagi segala cerita, dan berkenalan kepada banyak orang-orang baru. Namun sayangnya sosial media tidak selalu berdampak baik bagi remaja.

Sosial media dapat menjadikan remaja menjadi pribadi yang tertutup, menimbulkan efek ketagihan, serta mengesampingkan orang-orang disekitarnya. Kebanyakan remaja akan lebih asyik berinteraksi dengan smartphone dibanding dengan orang secara nyata. Hal tersebut karena oleh komunitas online yang mereka miliki tidak terlalu membebani. Mereka dapat dengan mudah memalsukan dan mengganti karakternya. Biasanya remaja menganggap sosial media adalah tempat yang tepat untuk bereksperimen, mencoba berbagai karakter, dan salah satu wadah yang dapat mereka gunakan mengeksplorasi diri untuk kepentingan pencarian jati diri. Namun seperti yang telah diulas, sosial media dapat menimbulkan efek ketagihan. Felita, 
et al (2016) dari penggunaan sosial media yang diharapkan oleh kebanyakan remaja adalah feedback dari pengguna sosial media lainnya. Hal tersebut karena feedback dalam sosial media mereka anggap sebagai perhatian terhadap dirinya. Selain perhatian mereka juga sering menganggap feedback tersebut adalah bentuk dukungan, motivasi atau sebagainya. Peg dan Streep (2013) dalam Felita, et al (2016) juga menuliskan terdapat 4 alasan remaja menggunakan sosial media, yang pertama adalah untuk mendapatkan perhatian, dan dukungan. Berdasarkan penelitian Felita, et al (2016) mengatakan bahwa like, comment, dan follow back merupakan kegiatan sosial media yang dianggap sebagai perhatian dan dukungan oleh remaja. Hal ini tentu akan dapat menimbulkan dampak buruk bagi remaja, karena mereka akan merasa lebih diperhatikan pada saat bersosial menggunakan media sosial dibandingkan bersosial secara nyata. Dampaknya mereka akan lebih merasa nyaman ketika berkomunikasi di sosial media, lebih menutup diri terhadap kehidupan masyarakat yang sesungguhnya dan aman untuk melampiaskan semua hal.

Posisi ketiga, pilihan terbanyak adalah game. Selain sosial media, dan mencari informasi remaja juga sering menggunakan internet untuk bermain game online. Remaja sering menjadikan game online sebagai aktivitas yang menyenangkan. Remaja saat ini cenderung memilih game online daripada offline. Hal ini juga disampaikan oleh Kurniawan (2015) yang menyatakan game online lebih diminati remaja karena game online mempunya tantangan yang lebih daripada game offline. Hal tersebut dikarenakan game online memiliki lawan langsung, sedangkan game offline hanya berupa aplikasi game tanpa lawan yang sebenarnya. Menurut Salainty (2015) game online lebih menarik dari pada game offline karena game online memiliki daya tarik tersendiri diantaranya, dapat menjadi salah satu wadah untuk menyalurkan emosi dengan tantangan yang lebih besar daripada game offline. Game online juga dapat menambah teman. Hal ini karena pada saat bermain game online remaja memiliki lawan yang sesungguhnya. Tak jarang mereka dapat berkomunikasi satu sama lain melalui chatting yang tersedia di dalam game, sehingga remaja dapat menjadikan game online sebagai media untuk menambah pertemanan. Semua hal tersebut adalah alasan yang melatarbelakangi remaja untuk lebih memilih game online.

Sedangkan pilihan membaca berita dan menonton film memiliki jumlah pemilih dengan jumlah angka sama, yaitu masing-masing memiliki angka 6 dengan persentase 9,5\%. Hal ini karena minat baca masyarakat Indonesia yang cendrung rendah. Ternyata siswa SMP X pun tidak memiliki ketertarikan yang tinggi terhadap berita. Menurut sebuah penelitian mengungkapkan diantara 17.000 responden yang berusia 10-19 tahun dengan 2 kelompok antaranya 10-14 tahun dan kelompok usia 15-19 tahun. Pada kelompok usia 10-14 tahun hanya terdapat $4 \%$ responden yang memiliki kebiasaan membaca, sedangkan pada kelompok usia 15-19 tahun hanya sebanyak 9\% responden yang memiliki kebiasaan atau ketertarikan terhadap kegiatan membaca (Safiera, 2016). Tujuan berinternet selanjutnya yang memiliki angka sama dengan membaca adalah menonton film. Hal ini karena pengetahuan siswa SMP $X$ yang minim perihal film.

Berdasarkan ulasan tersebut dapat disimpulkan bahwa 3 pilihan terbanyak ketika siswa ditanya mengenai tujuan berinternet adalah mencari informasi, bersosial media dan games. Hal tersebut ternyata sejalan dengan Broto (2014) yang menyatakan terdapat 3 motivasi utama remaja untuk mengakses internet, yaitu pencarian informasi, media sosial dan konten-konten hiburan.

\section{Informasi Yang Sering Dicari Di Internet}

Tabel 4 sebelumnya telah menjelaskan bahwa siswa SMP X sering menggunakan internet dengan tujuan utama adalah mencari informasi. Menurut Husni dan Fatulloh (2016) menyatakan dalam hasil surveynya, $92 \%$ remaja menggunakan internet untuk kepentingan tugas sekolah. Hal ini ternyata terbukti dengan hasil penelitian ketika siswa SMP $\mathrm{X}$ ditanya informasi yang paling sering 
dicari. Jawaban terbanyak adalah informasi pendidikan dengan jumlah 27 siswa atau sama dengan persentase $42,9 \%$. Ternyata Halim (2015) juga telah membuktikan bahwa remaja menggunakan internet untuk mengerjakan tugas-tugas sekolahnya, di antara 3 responden yang ditanya mengenai tujuan berinternet, semua menjawab untuk mengerjakan tugas sekolah.Alasan remaja menggunakan internet untuk mengerjakan tugas adalah di dalam internet seluruh informasi dapat dicari dengan mudah, dapat diakses kapan saja dan dimana saja, serta informasi yang tersedia di internet tidak terbatas bagi siapa saja. Hal ini karena setiap orang memiliki kebebasan untuk berpendapat dalam berinternet. Hal tersebut juga telah di lindungi oleh Undang-Undang No. 11 Tahun 2008 Tentang Informasi dan Traksaksi Elektronik. Sebenarnya hal ini selaras dengan hasil analisa data pada tabel 4 , bahwa sebagian besar remaja menggunakan internet untuk mencari informasi. Kominfo dalam webnya menuliskan pencarian informasi dalam internet yang dilakukan remaja sering di dorong oleh tugas-tugas sekolah. Namun, masalah baru muncul ketika banyak pihak yang menyalah gunakan internet sebagai media penyebaran berita hoax (tidak benar). Karena kebanyakan remaja menerima begitu saja segala informasi yang tersedia diinternet tanpa mempertimbangkan sumbernya. Juliswara (2017) menyatakan bahwa penyebaran berita hoax juga dapat membuat kelompok terpelajar sekalipun tidak bisa membedakan mana berita yang benar, atau hoax. Dengan ini, kebebasan remaja untuk mencari informasi pendidikan di internet juga harus dibawah pengawasan sehingga remaja tidak terjebak dalam persepsi yang dipengaruhi oleh berita hoax.

Tiga banding satu adalah angka perumpamaan yang tepat jika melihat hasil dari analisa data pada pilihan informasi pendidikan (27 responden) jika dibandingkan dengan informasi kesehatan (9 responden) dan pilihan informasi kuliner (9 responden). Hal ini dikarenakan remaja merasa informasi kesehatan hanya dicari berdasarkan urgenitasnya. Padahal menurut Pratiwi (2013) remaja sebenarnya menghadapi masalah kesehatan yang kompleks. Namun remaja sering kali diasumsikan sebagai kelompok yang sehat. Hal ini dikarenakan remaja sering di pengaruhi oleh berbagai hal di sekelilingnya (Wahyudi, 2013) termasuk sebutan yang sering diberikan kepada mereka. Selama ini remaja sering disebut sebagai kelompok yang kuat, sehat serta produktif, maka mereka (remaja) akan merasakan hal yang sama seperti anggapan orang-orang sekitarnya sehingga ia lupa akan kondisi kesehatan yang sebenarnya. Maka remaja merasa tidak perlu mencari informasi kesehatan. Hal ini juga disebutkan oleh Goold (2003) dalam Ernawati, et al (2014) yang menyatakan remaja banyak memanfaatkan internet sebagai media mencari infomasi atau $e$ mailing, dan sangat sedikit untuk alasan mencari informasi kesehatan.

Sedangkan informasi kuliner dengan angka $9(14,3 \%)$ dipilih oleh mereka yang gemar memasak. Hanya mereka yang berjenis kelamin perempuan yang memilih infromasi kuliner. Hal tersebut ada hubungannya dengan naluri. Menurut Putra (2015) yang menyatakan bahwa naluri wanita dan pria berbeda. Pada saat anak-anak naluri anak perempuan akan bermain boneka dan masak-masakan sedangkan laki-laki cenderung akan bermain mobil-mobilan. Namun ternyata tidak semua responden perempuan memilih memasak sebagai materi pencarian infromasinya dalam berinternet, diantara 47 responden perempuan hanya 9 diantaranya yang memilih informasi kuliner sebagai kegiatan pencarian di internet.

Sedangkan untuk informasi berita hanya 7 responden dengan persentase $11,1 \%$. Hal ini tentu ada hubungannya dengan ketertarikan remaja terhadap bahan bacaan yang telah dibahas sebelumnya. Pada faktanya remaja Indonesia memang memiliki minat baca yang rendah terlebih remaja lebih suka membuka dan update di sosial media daripada update berita-berita terbaru. 11 angka lainnya di peroleh oleh pilihan lainnya. Remaja merasa kebiasaannya mengunakan internet dalam mencari informasi tidak ada pada pilihan yang tersedia.

Sebagian besar responden mengaku pernah mencari informasi 
Table 5. Penggunaan Internet Dalam Mencari Informasi Kesehatan

\begin{tabular}{|c|c|c|}
\hline Pilihan & Frekuensi & $\%$ \\
\hline \multicolumn{3}{|c|}{$\begin{array}{l}\text { Menggunakan Internet Untuk } \\
\text { Mencari Informasi Kesehatan }\end{array}$} \\
\hline $\mathrm{Ya}$ & 43 & 68,3 \\
\hline Tidak & 20 & 31,7 \\
\hline \multicolumn{3}{|c|}{$\begin{array}{c}\text { Sebarapa Sering Mencari Informasi } \\
\text { Kesehatan Melalui Internet }\end{array}$} \\
\hline Sehari Sekali & 8 & 12,7 \\
\hline $\begin{array}{l}\text { Seminggu } \\
\text { Sekali }\end{array}$ & 24 & 38,1 \\
\hline $\begin{array}{l}\text { Sebulan } \\
\text { Sekali }\end{array}$ & 31 & 49,2 \\
\hline \multicolumn{3}{|c|}{$\begin{array}{c}\text { Informasi Kesehatan Yang Sering } \\
\text { Dicari Melalui Internet }\end{array}$} \\
\hline $\begin{array}{l}\text { Makanan } \\
\text { Sehat }\end{array}$ & 9 & 14,3 \\
\hline $\begin{array}{c}\text { Keluhan } \\
\text { Penyakit } \\
\text { Yang }\end{array}$ & 31 & 49,2 \\
\hline $\begin{array}{l}\text { Dirasakan } \\
\text { PHBS }\end{array}$ & 15 & 23,8 \\
\hline Diet Sehat & 8 & 12,7 \\
\hline
\end{tabular}

mengenai kesehatan dengan menggunakan media internet. Sebanyak $43 \quad(68,3 \%)$ menjawab pernah mencari informasi kesehatan melalui internet. Sedangkan 20 $(31,7 \%)$ lainnya memilih tidak. Artinya tidak semua responden pernah mencari informasi mengenai kesehatan di internet. Namun berbeda ketika responden ditanya mengenai frekuensinya untuk mencari informasi kesehatan di internet. Mayoritas responden mengaku mencari informasi kesehatan paling tidak sebulan sekali dengan angka 31 (49,2\%), disusul dengan pilihan seminggu sekali dengan angka 24 $(38,1 \%)$ dan jawaban minoritas didapat oleh pilihan sehari sekali dengan angka 8 $(12,7 \%)$.

Ternyata faktor yang menyebabkan remaja jarang membuka atau mencari informasi kesehatan dibanding informasi lainnya adalah mencari informasi kesehatan hanya remaja lakukan ketika mereka merasakan keluhan. Hal ini ditunjukkan dengan hasil analisa data yang mayoritas responden mengaku akan mencari informasi kesehatan jika merasakan keluhan dengan angka 31 $(49,2 \%)$, maka mereka akan mencari informasi kesehatan sesuai dengan keluhan yang mereka rasakan. Namun tak selamanya keluhan yang mereka rasakan dapat dicari di internet. Hal ini dikarenakan informasi kesehatan secara online kurang efektif untuk menangani persoalan gangguan kesehatan yang bersifat kuratif (Siswanta. 2015). Maka dapat disimpulkan bahwa informasi kesehatan yang tersedia di internet merupakan informasi dasar yang lebih bersifat preventif dan promotif untuk mengurangi peluang keparahan.

PHBS berada di posisi kedua dengan angka $15(23,8 \%)$. Hal ini sejalan dengan karakteristik remaja yang identik dengan kepopularitasan, serta ingin selalu diperhatikan. Bersih dan sehat merupakan salah satu kunci yang dapat memengaruhi perhatian seseorang. Maka remaja berusaha terlihat selalu bersih dan sehat, sehingga orang-orang memperhatikannya. Hal ini terlihat dari perilaku remaja yang ingin selalu terlihat cantik atau ganteng serta ingin terlihat sebagai remaja yang kuat dan dapat melakukan segalanya. Namun sayangnya hanya sebagian siswa yang peduli dengan hal tersebut. Pilihan jawaban informasi kesehatan mengenai makanan sehat dipilih oleh $9(14,3 \%)$ responden. Hal ini ternyata sejalan dengan kegemaran memasak sebagai naluri wanita yang telah diulas sebelumnya. Responden yang memilih memasak pada tipe informasi yang sering dicari memiliki jumlah yang sama dengan informasi kesehatan mengenai makanan sehat, yaitu sebanyak 9 (14,3\%). Disisilain yang memilih jawaban keduanya adalah responden yang sama. Dapat disimpulkan bahwa, kesembilan responden tersebut memiliki ketertarikan yang sama yaitu masak-memasak, maka dari itu responden tersebut sering mencari informasi kesehatan seputar makanan sehat.

Posisi terakhir adalah diet sehat dengan jumlah $8 \quad(12,7 \%)$ responden. Banyak penelitian menyatakan bahwa kebanyakan akan melakukan diet, bahkan tak jarang juga yang melakukan diet ekstreme hanya untuk mendapatkan citra tubuh yang baik (Lintang, 2015). Namun hal tersebut tidak sejalan dengan hasil 
analisa yang dilakukan oleh peneliti. Peneliti menemukan hanya sebagian kecil responden yang tertarik untuk mencari informasi kesehatan mengenai diet sehat melalui internet. Setelah ditelaah, ternyata perilaku diet cenderung dilakukan oleh remaja akhir, sedangkan penelitian ini dilakukan kepada siswa SMP $X$ yang merupakan remaja pada tahap awal.

Table 6. Perilaku Setelah Mendapatkan Informasi Kesehatan Melalui Internet

\begin{tabular}{|c|c|c|}
\hline Pilihan & Frekuensi & $\%$ \\
\hline \multicolumn{3}{|c|}{$\begin{array}{c}\text { Informasi Kesehatan Cukup } \\
\text { Membantu }\end{array}$} \\
\hline Ya & 30 & 47,6 \\
\hline Tidak & 33 & 52,4 \\
\hline \multicolumn{3}{|c|}{$\begin{array}{l}\text { Yang Dilakukan Setelah } \\
\text { Mendapatkan Informasi } \\
\text { Kesehatan Di Internet }\end{array}$} \\
\hline $\begin{array}{c}\text { Mengikut } \\
\text { Saran Yang } \\
\text { Diberikan }\end{array}$ & 18 & 28,6 \\
\hline $\begin{array}{l}\text { Membagika } \\
\text { n Informasi } \\
\text { Kepada } \\
\text { Teman }\end{array}$ & 19 & 30,2 \\
\hline $\begin{array}{c}\text { Melupakan } \\
\text { Begitusaja }\end{array}$ & 17 & 27,0 \\
\hline $\begin{array}{c}\text { Menanyaka } \\
\mathrm{n}\end{array}$ & 9 & 14,32 \\
\hline $\begin{array}{c}\text { Kesebanara } \\
\text { nya Kepada } \\
\text { Ahli } \\
\text { Kesehatan }\end{array}$ & & \\
\hline
\end{tabular}

Sebagian besar responden menganggap informasi kesehatan yang ada di internet tidak dapat membantu mereka, sebanyak 33 responden atau 52,4\%. Sedangkan $30 \quad(47,6 \%)$ menjawab informasi yang ada di internet dapat membantu mereka. Penelitian ini membuktikan bahwa remaja memiliki hobi berteman. Hal tersebut dikarenakan sebagian besar responden mengaku akan menyalurkan infomasi kesehatan yang mereka dapatkan melalui internet kepada teman-temannya, jawaban ini dipilih oleh 29 responden dengan persentase $30,2 \%$. Menurut Samil (2000) remaja suka berbagi segala hal dengan teman sebayanya, mereka cenderung lebih suka berbicara dengan teman sebayanya dibandingkan dengan orang lainnya. Mereka lebih suka mendiskusikan informasi kesehatan yang mereka dapatkan dengan teman sebayanya. 18 responden $(28,6 \%)$ mengaku akan mengikuti saran yang diberikan oleh informasi kesehatan yang mereka dapatkan di internet. Hal ini juga sejalan dengan karakteristik remaja yang suka bereksperimen. Mereka akan cenderung mencoba berbagai hal yang baru mereka temui. Begitupun dengan anjuran dari internet perihal informasi kesehatan yang mereka cari. Namun tak sedikit pula responden yang akan mengabaikan informasi kesehatan yang mereka dapatkan. Biasanya remaja yang seperti ini tidak merasakan manfaat dari informasi tersebut maka dari itu mereka akan melupakan dan tidak memberikan respon apapun terhadap informasi yang mereka dapatkan.

Sebelumnya telah dibahas mengenai maraknya berita hoax yang tersebar di internet serta ketidakmampuan remaja untuk menyaring informasi dengan mempertimbangkan kebenaran dan sumbernya. Hal ini sejalan dengan hasil analisa data yang mengungkapkan, hanya terdapat 9 siswa dengan persentase $14,32 \%$ yang menganggap informasi tersebut merupakan sebuah informasi yang harus di check kebenarannya.

Internet dengan kebebasan penggunaan dan dampak negatifnya, serta kondisi fisik remaja yang terkadang mengharuskan mereka memakai internet untuk kepentingan kesehatan, menyebabkan remaja dengan ciri khasnya memerlukan pengawasan lebih intensif dibanding dengan masa pertumbuhan lainnya. Hal ini bertujuan untuk kebaikan remaja sehingga remaja tidak terjerumus dalam informasi yang salah, serta tidak membagikan informasi yang salah

\section{SIMPULAN}

Berdasarkan penelitian, maka dapat disimpulkan bahwa guru merupakan role model utama dari pengenalan internet terhadap siswa SMP X. sebagian besar responden pernah memanfaatkan internet untuk mencari informasi kesehatan. Sedangkan frekuensi waktu yang paling 
banyak dipilih oleh responden adalah paling tidak 1 bulan sekali.

\section{DAFTAR PUSTAKA}

Ali, Mohammad., Mohammad, Ansori. 2012. Psikologi Remaja Perkembangan Peserta Didik. Jakarta: PT. Bumi Aksara.

Aprilia, Alfa Tirza. 2015. Membaca Buku Versus Internet, Lebih Suka Mana?. Dalam https://student.cnnindonesia.com/inspirasi/ Publikasi. Universitas Aisyiyah Yogyakarta.

Ayuwuragil, Kustin. 2018. Netizen Lebih Memilih Ponsel Pintar Dibandingkan Laptop. $\quad$ Dalam https://www.cnnindonesia.com/teknologi/2 0180221100858-192-277653/netizenlebih-memilih-ponsel-pintar-dibandingkanlaptop. Diakses pada 2 April pk 21.56.

Azizah. 2013. Kebahagiaan Dan Permasalahan Di Usia Remaja (Penggunaan Informasi Dalam Pelayanan Bimbingan Individual). Jurnal Bimbingan Konseling Islam. Vol 4 (2): 295-316.

Basrowi., Juariyah, Siti. 2010. Analisis Kondisi Sosial Ekonomi Dan Tingkat Pendidikan Masyarakat Desa Srigading, Kecamatan Labuhan Maringgai, Kabupaten Lampung Timur. Jurnal Ekonomi dan Pendidikan. Vol 7 (1): 58-81.

Broto, Gatot S. 2014. Riset Kominfo Dan Unicef Mengenai Perilaku Anak Dan Remaja Dalam Menggunakan Internet. Dalam https://kominfo.go.id/index.php/content/de tail/3834/Siaran+Pers+No.+17-PIH-

KOMINFO-2-

2014+tentang+Riset+Kominfo+dan+UNIC $\mathrm{EF}+$ Mengenai+Perilaku+Anak+dan+Rema ja+Dalam+Menggunakan+Internet+/0/siar an_pers. Diakses pada 03 April 2018 pk 16.11 .

Ediati, Annastasia. 2015. Profil Problem Emosi/Perilaku Pada Remaja Perlajar SMP-SMA Di Kota Semarang. Jurnal Psikologi Undip. Vol 4 (2). 190-198. 20151101093252-327-88664/membacabuku-versus-internet-lebih-suka-mana/. Diakses pada 06 April 2018 pk. 06.07.

Aryatmi, S., Lobby, L., Laviabus, S., 1991. Masalah Remaja. Semarang: Satya Wacana.

Ayudiah, Febra. 2017. Faktor-faktor Yang Mempengaruhi Pengetahuan Remaja Tentang Mandi Besar Pada Siswa SMA 7 Muhammadiyah Yogyakarta. Naskah Ernawati, Hery,. Hapsari, Elsi Dwi,. Lusmilasari, Lely. 2014. Penggunaan Sistem Informasi Berbasis Website Pada Remaja. Jurnal Ners. Vol 9 (2): 194-202.

Fajar, Adiatmaputra. 2010. Remaja Butuh Perhatian Lebih Daripada Anak-anak. Dalam

(http://www.tribunnews.com/lifestyle/2010 /12/13/remaja-butuh-perhatian-lebihdaripada-anak-anak). Diakses pada 31 Maret 2018 pk. 11.10.

Felita, Pamea., Siahaja, Christine., Wijaya, Vania., dan Melisa, Gracia. 2016. Pemakaian Media Sosial Dan Self Concept Pada Remaja. Jurnla Ilmiah Psikologi Manasa. Vol 5 (1): 30-41.

Halim, Nurdin Abd. 2015. Penggunaan Media Internet Di Kalangan Remaja Untuk Mengembangkan Pemahaman Keislaman. Jurnal Risalah. Vol 26 (3): 132-150.

Husni, Emir Mauludi,. Fatulloh Agus. 2016. Kategori Pengguna Internet Di Kalangan Pelajar SD Dan SMP Menggunakan Metode Twostep Cluster. Seminar Nasional Aplikasi Teknologi Informasi (SNATi). ISSN: 1907-5022.

Juliswara, Vibriza. 2017. Mengembangkan Model Literasi Media Yang Berkebhinekaan Dalam Menganalisis Informasi Berita Palsu (Hoax) Di Media Sosial. Jurnal Pemikiran Sosiologi. Vol 4 (2): $142-164$.

Kurniawan, FA. 2015. Motif Remaja Dalam Bermain Game Online (Studi Kasus Pada Remaja Di Salatiga). Dalam http://repository.uksw.edu/bitstream/12345 
6789/10091/2/T1_362008024_BAB\%20I. pdf. Diakses pada 04 April 2018 pk 15.36.

Kusuma, Alan. 2016. Cara mengatasi Kecanduan Internet. Dalam (http://intisari.grid.id/read/0338901/5-caramengatasi-kecanduan-internet). Diakses pada 02 April 2018 pk. 09.58.

Papalia, D. E., Old, S. W., Feldman, \& R. D. 2001. Perkembangan Manusia (terjemahan A. K. Anwar). Jakarta: Salemba Humanika.

Pratama, Adiatmaputra Fajar. 2010. Remaja Butuh Perhatian Lebih Daripada Anak-Anak. Dalam (http://www.tribunnews.com/lifestyle/2010 /12/13/remaja-butuh-perhatian-lebihdaripada-anak-anak). Diakses pada 01 April pk 11.28.

Pratiwi, Rinni Yudhi. 2013. Kesehatan Remaja Di Indonesia. Dalam http://www.idai.or.id/artikel/seputarkesehatan-anak/kesehatan-remaja-diindonesia. Diakses pada 05 April 2018 pk 05.16 .

Putra, Muhammad Arief Hidayatullah. 2015. "Naluri Wanita" Dalam Keilmuan Psikologi.

Dalam https://www.kompasiana.com/arif_hidayat ullah/naluri-wanita-dalam-keilmuanpsikologi_566cf5b9d37a617e1095e029. Diakses pada 05 April 2018 pk. 05.43.

Ramadhani, Graifhan. 2003. Modul Pengenalan Internet. Universitas Muhammadiyah Malang. Dalam (http://directory.umm.ac.id/tik/pengenalan _internet.pdf). Diakses pada 30 Maret 11.35 .

Sa'id. M. A. 2015. Mendidik Remaja Nakal: Panduan Praktis Seni Mendidik Dan Berinteraksi Dengan Remaja. Yogyakarta: Semesta Hikmah.

Safiera, Alissa. 2016. Survei Neilsen: Hanya 9\% Remaja Indonesia Yang Masih Baca Media Cetak. Dalam https://wolipop.detik.com/read/2016/10/19/ 184850/3324740/860/survei-nielsenhanya-9-remaja-indonesia-yang-masih- baca-media-cetak. Diakses pada 04 April 2018 pk 15.57.

Salainty, Falyana R. 2015. Pengaruh Permainan Internet Terhadap Perilaku Remaja Di Kelurahan Karombasan Utara. Journal Acta Dunia. Vol 4 (1).

Samil, Ali. 2000. Panduan Praktis Bagi Orang Tua Mendampingi Remaja Meraih Sukses. Jakarta: Pustaka Obor Indonesia.

Saputri, Ocnatias Eka. 2014. Gambaran Penggunaan Internet Pada Anak Remaja Di SMP Muhammadiyah 1 Kartasura. Skripsi. Universitas Muhammadiyah Surakarta.

Sarmin. 2017. Konselor Sebaya: Pemberdayaan Teman Sebaya Dalam Sekolah Guna Menanggulangi Pengaruh Negatif Lingkungan. Jurnal Risat dan Konseptual. Vol 2 (1): 102-112.

Sidharta, Lani. 1996. Sistemn Informasi Bisnis: Analisa dan Desain Sistem Informasi Bisnis. Jakarta: Media Komputindo.

Simbolon, Santi Sari. 2017. Pentingnya Saran Dan Prasarana Dalam Pendidikan. Dalam http://scdc.binus.ac.id/himpgsd/2017/03/sa ranadanprasaranapendidikan/. Diakses pada 04 April pk 18.13.

Siswanta. 2015. Informasi Kesehatan Di Media Online. Jurnal Ilmu Komunikasi. Vol 13 (3): 210-223.

Tekun. 2016. Karakteristik Dan Permasalahan Psikologi Remaja. Dalam (http://www.psikoma.com/karakteristikdan-permasalahan-psikologi-remaja/). Diakses pada 02 April pk 11.25.

Undang-Undang No. 11 Tahun 2008 Tentang Informasi dan Traksaksi Elektronik.

Wahyudi. 2013. Tinjauan Tentang Perilaku Konsumtif Remaja engunjung Mall Sama Rinda Central Plaza. E-journal Sosiologi. Vol 1 (4): 26-36. Dalam http://ejournal.sos.fisipunmul.ac.id/site/wpcontent/uploads/2013/11/Jurnal\%20wahyu 
di\%20(11-07-13-07-45-39).doc. Diakses pada 05 April 2018 pk 05.01. 